\title{
Agonist- and Reflex-Evoked Internalization of Metabotropic Glutamate Receptor 5 in Enteric Neurons
}

\author{
Min-tsai Liu and Annette L. Kirchgessner \\ Department of Physiology and Pharmacology, State University of New York Health Science Center at Brooklyn, Brooklyn, \\ New York, 11203
}

\begin{abstract}
We demonstrate that metabotropic glutamate receptor 5 (mGluR5) is present in the guinea pig ileum. A punctate ring-like distribution of immunoreactivity is found on the soma of a subset of neurons, consistent with an association of mGluR5 with the plasma membrane. mGluR5-containing cells in the submucosal plexus are predominantly noncholinergic and contain vasoactive intestinal peptide, a marker of secretomotor neurons. Using immunocytochemistry in conjunction with confocal microscopy, we show that the mGluR5 undergoes agonist- and reflex-evoked internalization that is inhibited by the group I antagonist 1-aminoindan-1,5-dicarboxylic acid. In
\end{abstract}

The gut is the only organ that is capable of manifesting reflex activity in the absence of input from the brain or spinal cord. Intrinsic reflexes occur in the bowel because primary afferent neurons and interneurons, in addition to the motoneurons that innervate effector cells, are all present in the enteric nervous system (ENS) (Furness et al., 1994; Gershon et al., 1994). The complexity of the functions controlled by the ENS is reflected in an equally complex organization that resembles that of the CNS more than the remainder of the peripheral nervous system. Many different classes of neurotransmitter have been found in the gut, including glutamate (Liu et al., 1997), the major excitatory neurotransmitter of the brain.

Enteric neurons express the neuronal glutamate transporter EAAC1 (Liu et al., 1997), and both NMDA (Burns et al., 1994; Burns and Stephens, 1995; Liu et al., 1997) and non-NMDA (AMPA and kainate) receptors (Liu et al., 1997; Kirchgessner et al., 1997), and a subset of enteric neurons that have been demonstrated previously to be sensory (Bornstein and Furness, 1988; Kirchgessner et al., 1992) are glutamatergic. Pharmacological studies are also consistent with the idea that neurogenic motile (Wiley et al., 1991) or secretory (Rhoads et al., 1995) responses of the gut involve enteric glutamatergic receptors. Moreover, excessive activation of glutamate receptors causes excitotoxicity in the gut (Kirchgessner et al., 1997).

The ENS probably also contains metabotropic glutamate receptors (mGluR), which are members of the G-protein-coupled receptor family. A delayed slow depolarization, which resembles

\footnotetext{
Received Jan. 11, 2000; accepted Feb. 11, 2000.

This work was supported by National Institutes of Health Grant NS35951 (A.L.K.). We thank Dr. Robert Wenthold for critically reading this manuscript and for his generous supply of antibodies.

Correspondence should be addressed to Dr. Annette Kirchgessner, Department of Physiology and Pharmacology, State University of New York Health Science Center at Brooklyn, 450 Clarkson Avenue, Box 29, Brooklyn, NY 11203. E-mail: akirchgessner@netmail.hscbklyn.edu.

Copyright (c) 2000 Society for Neuroscience $0270-6474 / 00 / 203200-06 \$ 15.00 / 0$
}

addition, group I mGluR antagonists reduce the distensioninduced phosphorylation of cAMP-responsive element-binding protein in enteric neurons and attenuate both glutamate- and group I agonist-induced depolarizing responses and slow synaptic events in submucosal neurons. These findings support the idea that mGluRs play a role in enteric reflexes and suggest that internalization might be a major mechanism for regulation of mGluR activity.

Key words: glutamate; electrophysiology; DHPG; CHPG; AIDA; S-4CPG; MPEP; $p C R E B$

a G-protein-dependent effect (Bertrand and Galligan, 1995), is produced in myenteric neurons by application of glutamate (Liu et al., 1997). At present, eight different mGluRs have been cloned, termed mGluR1-mGluR8 (Pin and Duvoisin, 1995). On the basis of their sequence similarity, pharmacology and signal transduction mechanisms, mGluRs have been classified into three groups. Group I receptors (mGluR1 $\alpha$ and mGluR5), which are coupled to phospholipase $\mathrm{C}$, activate protein kinase $\mathrm{C}$ and release $\mathrm{Ca}^{2+}$ from intracellular stores (Masu et al., 1991; Abe et al., 1992; Aramori and Nakanishi, 1992). Group II (mGluR2 and mGluR3) and group III (mGluR4 and mGluR6-mGluR8) receptors are negatively coupled to adenylase cyclase.

In the present study, we demonstrate that mGluR5 is present in the guinea pig gut, and we show that mGluR5 represents receptors that undergo agonist- and reflex-evoked internalization. Blockade of group I mGluRs prevents internalization, reduces the distension-induced phosphorylation of cAMP-responsive element-binding protein (pCREB) in enteric neurons, and inhibits both glutamate- and group I agonist-induced depolarizing responses and slow excitatory synaptic events in submucosal neurons. These findings are consistent with the idea that mGluRs play a role in enteric reflexes and suggest that internalization might be a major mechanism for regulation of mGluR activity.

Parts of this work have been published previously in abstract form (Kirchgessner and Liu, 1996; Liu et al., 1998).

\section{MATERIALS AND METHODS}

Tissue preparation. Male guinea pigs (350-450 gm) were killed by $\mathrm{CO}_{2}$ inhalation followed by decapitation. This procedure has been approved by the Animal Care and Use Committee of State University of New York Health Science Center at Brooklyn. The bowel was removed and washed with oxygenated $\left(95 \% \mathrm{O}_{2}-5 \% \mathrm{CO}_{2}\right)$ Krebs' solution of the following composition (in mM): $\mathrm{NaCl} 121, \mathrm{KCl} 5.9, \mathrm{CaCl}_{2} 2.5, \mathrm{NaHCO}_{3}$ 14.3, $\mathrm{NaH}_{2} \mathrm{PO}_{4}$ 1.3, $\mathrm{MgCl}_{2}$ 1.2, and glucose 12.7.

Dissociation and culture of myenteric neurons. Guinea pig myenteric ganglia were isolated (Yau et al., 1989) and plated in the center of Matrigel (Becton Dickinson, Bedford, MA) and laminin $(10 \mu \mathrm{g} / \mathrm{ml}$; 
Boehringer Mannheim, Indianapolis, IN) -coated glass coverslips (12 $\mathrm{mm}^{2}$ ) and grown in $5 \% \mathrm{CO}_{2}$ with DMEM-F12K (Life Technologies, Grand Island, NY) supplemented with $10 \%$ (v/v) heat-inactivated fetal bovine serum (Life Technologies), 10\% (v/v) chick embryo extract, penicillin-streptomycin (100 U/ml and $100 \mu \mathrm{g} / \mathrm{ml}$; Life Technologies), gentamicin $(50 \mu \mathrm{g} / \mathrm{ml}$; Life Technologies), and cytosine arabinoside (10 $\mu \mathrm{M}$; Sigma, St. Louis MO).

Demonstration of mGluR5 immunoreactivity. Whole-mount preparations were generated (Kirchgessner and Gershon, 1988) and exposed to PBS containing $0.5 \%$ Triton X-100 and $4 \%$ horse serum for $30 \mathrm{~min}$. mGluR5 immunostaining was performed using an antibody raised against a C-terminal 21 amino acid peptide (diluted 1:1000) (Brakeman et al., 1997). mGluR5 was detected by donkey anti-rabbit secondary antibodies coupled to indocarbocyanine (Cy3) (1:2000; Jackson ImmunoResearch, West Grove, PA) or fluorescein isothiocyanate (FITC; 1:200; Kirkegaard and Perry, Gaithersburg, MD). Tissues were washed in PBS and then mounted with Vectashield (Vector Laboratories, Burlingame, CA). Elimination of the primary antibody or preabsorption with the immunogenic peptide blocked staining.

The neurochemistry of cells that display mGluR5 immunoreactivity were identified by using primary antibodies raised in different species in conjunction with species-specific secondary antibodies [goat anti-mouse (Kirkegaard and Perry) or donkey anti-goat and donkey anti-rat (diluted 1:200; Jackson ImmunoResearch)] coupled to Cy3 (1:2000). Primary antibodies were against calbindin (mouse monoclonal; diluted 1:100; Sigma) (Kirchgessner and Liu, 1999), calcitonin gene-related peptide (CGRP) (mouse monoclonal; diluted 1:200; Chemicon, Temecula, CA) (Kirchgessner and Liu, 1999), choline acetyltransferase (ChAT) (goat polyclonal; diluted 1:1000; Chemicon) (Kirchgessner and Liu, 1998), substance P (SP) (rat monoclonal; diluted 1:1000; Accurate Chemicals, Westbury, NY) (Kirchgessner and Liu, 1999), or vasoactive intestinal polypeptide (VIP) (mouse monoclonal; diluted 1:500; CURE/Gastroenteric Biology Center, Antibody/RIA Core, Los Angeles, CA) (Wong et al., 1996). Preparations were examined by using an LSM 410 laser scanning confocal microscope (Zeiss, Thornwood, NY) with a kryptonargon laser attached to a Zeiss Axiovert 100 TV microscope.

Agonist-induced internalization of mGluR5. Dissociated neurons were incubated in culture medium with the group I mGluR agonist $(S)$-3,5dihydroxyphenylglycine (DHPG) $(30 \mu \mathrm{M})$ for $1 \mathrm{hr}$ at $4^{\circ} \mathrm{C}$, to allow binding to receptors. Tetrodotoxin (TTX) $(1 \mathrm{nM})$ was included in the culture medium to allow the majority of the receptor to locate on the cell surface (Southwell et al., 1998). Cells were then rinsed and incubated in DHPG-free medium at $37^{\circ} \mathrm{C}$ for $1 \mathrm{hr}$ for internalization (Southwell et al., 1998). To label surface-expressed receptors, cells were incubated with an antibody (N-mGluR5) raised against an extracellular epitope of mGluR5 (amino acids 365-380) (Roche et al., 1999). Neurons were incubated with N-mGluR5 $(6 \mu \mathrm{g} / \mathrm{ml})$ on ice $(1 \mathrm{hr})$, washed in PBS, and fixed (30 min). The effect of the group I mGluR antagonist 1-aminoindan-1,5dicarboxylic acid (AIDA) $(10 \mu \mathrm{M})$ on agonist-induced internalization was determined by coapplication of AIDA and DHPG. Experiments on cultured neurons were repeated at least three times with two coverslips per observation.

Reflex-induced internalization of mGluR5. Segments of ileum $(n=4)$ were removed, placed in Krebs' solution containing nifedipine ( $1 \mu \mathrm{M})$ and scopolamine $(1 \mu \mathrm{M})$ to prevent movement of smooth muscles, and cut open along the mesenteric border. Each piece of gut was pinned, mucosal side up, in a Sylgard-coated Petri dish. The preparation was then stimulated by exposing the mucosa to vigorous bubbling with carbogen, according to the method of Southwell et al. (1998). Segments of gut were fixed without bubbling (control) or after $15 \mathrm{~min}$ with villous agitation in the presence or absence of AIDA $(10 \mu \mathrm{M})$.

For quantification of receptor internalization, mGluR5immunoreactive cells were imaged by confocal microscopy. The presence of receptor on the surface and in the cytoplasm was recorded. Internalization was said to have occurred when five or more clumps of fluorescence were present in the cytoplasm in a single optical section (Southwell et al., 1998).

CREB phosphorylation. Segments of guinea pig ileum were isolated and placed in Krebs' solution, as above. Intraluminal pressure was increased by inflating a stationary intraluminal balloon (Fogarty Biliary Balloon Probe; American Edwards Laboratories, Santa Ana, CA) with $0.05-0.45 \mathrm{ml}$ of Krebs', as described previously (Kirchgessner et al., 1996; Kirchgessner and Liu, 1999). In additional segments of bowel, distension of the balloon was performed in the presence of AIDA (10 $\mu \mathrm{M})$. At the end of the stimulation period, the tissues were transferred to ice-cold Krebs', pinned flat (mucosal side up) and fixed, as above.

Preparations of gut were incubated in rabbit anti-rat pCREB (diluted 1:1000; New England Biolabs, Beverly, MA) overnight at $4^{\circ} \mathrm{C}$ (Kirchgessner and Liu, 1999). The pCREB antibody is specific for CREB phosphorylated on Ser ${ }^{133}$. After washing, preparations were incubated with donkey anti-rabbit secondary antibodies coupled to Cy3 (1:2000; Jackson ImmunoResearch) for $3 \mathrm{hr}$. ChAT or calbindin was located simultaneously with pCREB by incubating the tissues with speciesspecific secondary antibodies coupled to FITC (diluted 1:200; Jackson ImmunoResearch). The number of pCREB-immunoreactive nuclei per enteric ganglion was determined as described previously (Kirchgessner and Liu, 1999).

Intracellular electrophysiology. Intracellular recordings (Liu et al., 1997) were obtained with a Axoclamp 2B amplifier (Axon Instruments, Foster City, CA) from submucosal neurons using glass microelectrodes filled with $2.0 \mathrm{M} \mathrm{KCl}$ (tip resistance of $80-180 \mathrm{M}$ [SCAP] $\Omega$ ). Cells were classified according to established criteria (Liu et al., 1997). The input resistance of the impaled cell was determined by injection of a 0.1-0.9 nA hyperpolarizing current pulse (40-100 msec duration). Synaptic potentials were evoked by focal electrical stimulation of interganglionic fiber tracts $(20 \mathrm{~Hz}$ for $500 \mathrm{msec}$ to $1 \mathrm{sec}$ ) with monopolar extracellular electrodes made from Teflon-insulated platinum wire $(25 \mu \mathrm{m}$ diameter). Data were recorded with a personal computer and Axoscope software (Axon Instruments). Data are expressed as means \pm SEM.

Compounds were either applied to neurons by ejection with pressure from a micropipette $(\sim 5.0 \mu \mathrm{m}$ diameter $)$ filled with a $20.0 \mathrm{~mm}$ solution or by addition to the fluid superfusing the preparations. Compounds used included the following: (1) from Tocris Cookson (Ballwin, MO), quisqualate, 2-methyl-6-(phenylethynyl)-pyridine (MPEP), (RS)-2-chloro-5hydroxyphenylglycine (CHPG), DHPG, $(S)$-4-carboxyphenylglycine $(S$ $4 \mathrm{CPG})$, AIDA, and $((2 S, 3 S, 4 S)-2$-methyl-2-(carboxycyclopropyl)glycine) (MCCG); (2) from Sigma, TTX; and (3) from Research Biochemicals (Natick, MA), glutamate.

\section{RESULTS}

\section{Distribution of mGluR5 immunoreactivity in the guinea pig ileum}

mGluR5 immunoreactivity was found in both enteric plexuses and the interganglionic connectives. A punctate ring-like distribution of immunoreactivity was found on the soma of a subset of neurons, consistent with an association of mGluR5 with the plasma membrane. In the submucosal plexus, the majority of mGluR5-postitive cells did not display ChAT immunoreactivity (Fig. $1 A, B$ ); therefore, they are predominantly noncholinergic. In addition, mGluR5-immunoreactive neurons did not contain CGRP or SP, which are found in submucosal primary afferent neurons (Fig. 1C1,C2; Kirchgessner et al., 1992; Grider, 1994). mGluR5-containing neurons displayed VIP immunoreactivity (Fig. 1D1,D2), which is a marker of noncholinergic secretomotor neurons (Keast, 1987).

mGluR5 immunoreactivity was also found in the myenteric plexus. Clusters of mGluR5 immunoreactivity encircled a subset of myenteric neurons, some of which contained the calcium binding protein calbindin (Fig. $1 E, F$ ). The majority of mGluR5 neurons did not contain calbindin.

\section{Agonist-induced internalization of mGluR5}

Many G-protein-coupled receptors internalize on prolonged exposure to agonist (Grady et al., 1997). In view of the association of mGluR5 with the plasma membrane, we examined whether mGluR undergoes agonist-induced internalization. Dissociated myenteric neurons were incubated with the group I-specific mGluR agonist DHPG $(30 \mu \mathrm{M})$ at $4^{\circ} \mathrm{C}$, washed, and warmed to $37^{\circ} \mathrm{C}$. Confocal images were obtained to examine the distribution of N-mGluR5 immunoreactivity. At $4^{\circ} \mathrm{C}, \mathrm{N}$-mGluR5 immunoreactivity was confined to the plasma membrane of the soma, as reported previously (Roche et al., 1999) (Fig. 2A). Plasma 


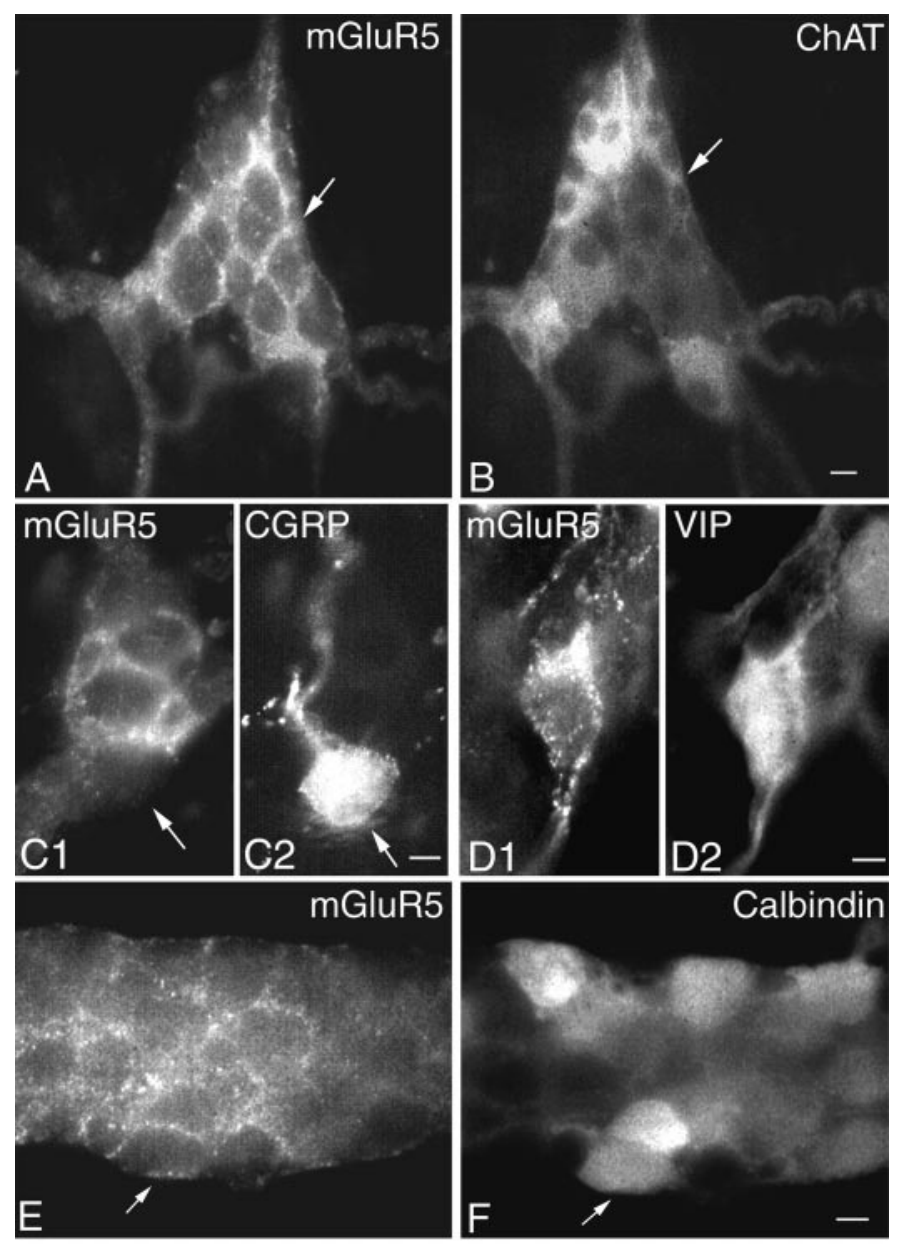

Figure 1. mGluR5 immunoreactivity in the enteric nervous system. $A-D$, Submucosal plexus. Clusters of mGluR5 encircle the soma of a subset of neurons. mGluR5-positive cells do not contain ChAT $(B)$ or calcitonin gene-related peptide $(C 1, C 2)$. mGluR5-immunoreactive neurons display VIP immunoreactivity $(D 1, D 2)$. $E, F$, Myenteric plexus. A subset of mGluR5-immunoreactive neurons $(E)$ contain calbindin $(F)$. Scale bars, $30 \mu \mathrm{m}$.

membrane-associated fluorescence had a punctate appearance. No fluorescence was detected in the nucleus. DHPG, within a 30 min period at $37^{\circ} \mathrm{C}$, caused $\mathrm{N}$-mGluR5 immunoreactivity to be localized in numerous endosomes in the soma (Fig. 2B). The internalization induced by DHPG was blocked by coapplication of the group I mGluR antagonist AIDA (10 $\mu \mathrm{M})$ (Fig. $2 C)$. These results demonstrate that mGluR5 represents receptors that are internalized after exposure to agonists.

\section{Reflex-induced internalization of mGluR5}

To clarify whether endocytosis of mGluR5 occurs in vivo, we determined whether mGluR5 became internalized during enteric reflex activity. Mucosal stimulation evokes reflexes that affect gut motility and has been shown to induce internalization of the neurokinin 1 receptor in enteric neurons (Southwell et al., 1998). Whole mounts of ileum were pinned out, mucosal side up, without movement of the villi for $30 \mathrm{~min}$, and then the villi were moved by bubbling with carbogen. In control preparations, mGluR5 immunoreactivity was confined to the plasma membrane of noncholinergic submucosal neurons (Fig. 2D), as described above. Movement of the villi resulted in the internalization of receptor in $80.0 \pm 3.0 \%$ of mGluR5-positive submucosal cells
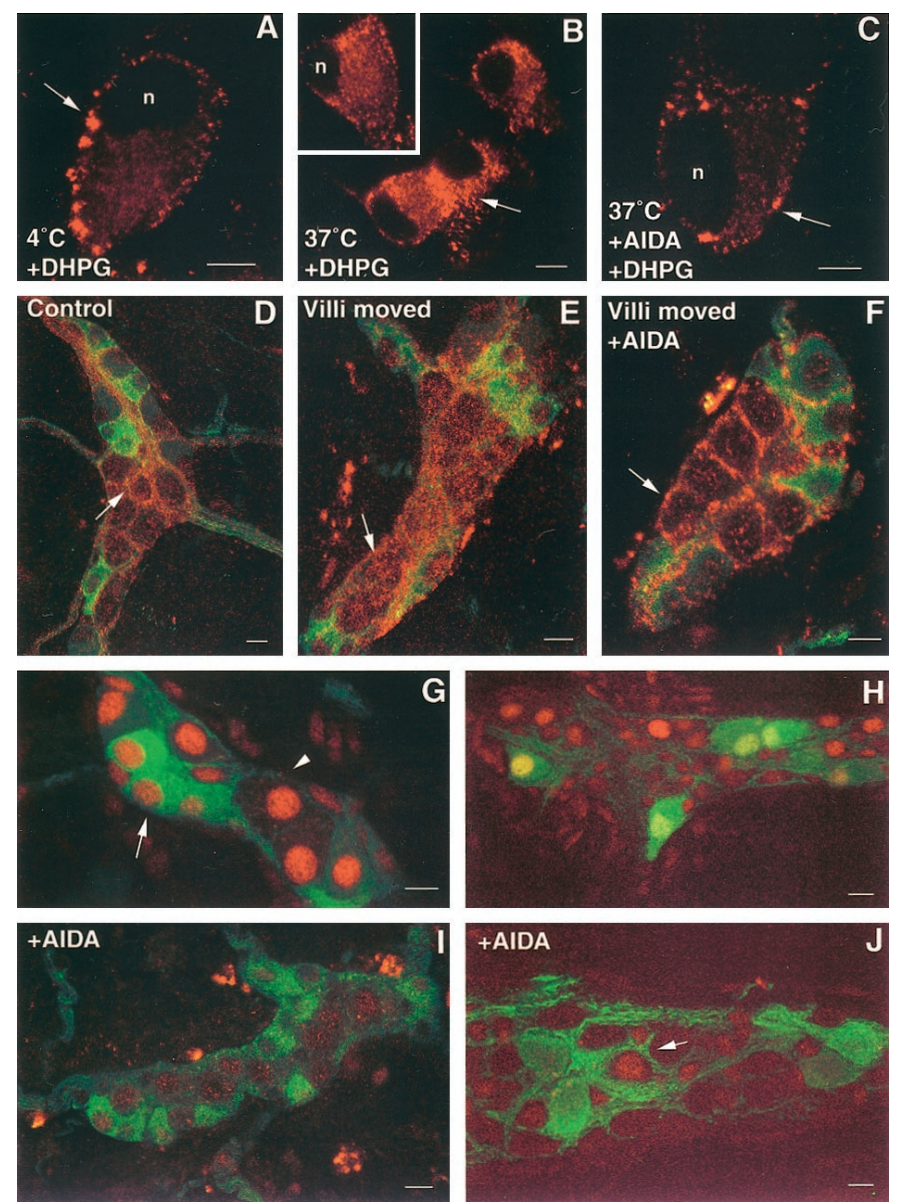

Figure 2. Agonist- and reflex-evoked internalization of mGluR5 in enteric neurons. $A-C$, Confocal images showing the localization of mGluR5 immunoreactivity (arrows) in dissociated neurons. Neurons were incubated with DHPG $(30 \mu \mathrm{M})$ for $1 \mathrm{hr}$ at $4^{\circ} \mathrm{C}$, washed, and incubated at $37^{\circ} \mathrm{C}$ for $0 \mathrm{~min}$ (control; $A$ ), $30 \mathrm{~min}(B)$, or in the presence of AIDA $(C)$. Arrows in $B$ indicate internalization of mGluR5 from the plasma membrane to the cytoplasm. $D-F$, Confocal images showing the localization of mGluR5 in submucosal neurons in tissue incubated without agitation $(D)$, in response to villous agitation $(E)$, and in response to villous movement in the presence of AIDA $(F)$. Internalized receptor $($ red $)$ is found in the cytoplasm of submucosal neurons that do not (arrowhead) contain ChAT immunoreactivity (green). $G-J$, pCREB immunoreactivity in enteric neurons in response to distension in the absence $(G, H)$ or presence $(I, J)$ of AIDA. $G$, pCREB-immunoreactive nuclei (red) are found in ChATpositive (green; arrow) and ChAT-negative (arrowhead) submucosal neurons (green). $\mathrm{H}$, A group of calbindin-immunoreactive neurons (green) displays pCREB immunoreactivity (red) in the myenteric plexus. $I, J$, AIDA blocks the expression of pCREB (red) in ChAT-immunoreactive submucosal neurons ( $I$; green) and in calbindin-immunoreactive myenteric neurons $(J$; green $)$; however, a subset of calbindin-negative myenteric neurons continue to express pCREB $(J$; arrow). Scale bars, $30 \mu \mathrm{m}$.

(Fig. 2E). After treatment of the preparations with AIDA (10 $\mu \mathrm{M})$, the distribution of mGluR5 was again associated with the membrane (Fig. $2 F$ ), and only $5.3 \pm 2.4 \%$ of mGluR5-positive neurons contained clumps of receptor in the cytoplasm (Fig. $2 F$ ).

\section{Effects of AIDA on distension-induced pCREB expression}

To determine whether the mGluR5 would be activated endogenously during enteric reflexes, we examined the effects of AIDA on the reflex-evoked activation of enteric neurons. Inflation of an intraluminal balloon was used to apply pressure to the mucosa 
A
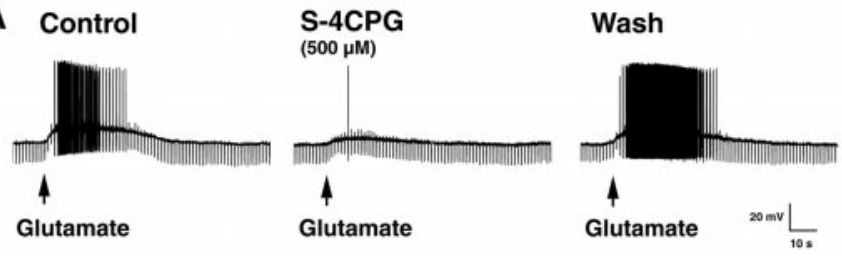

B
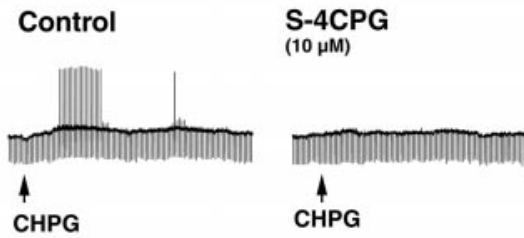

Wash

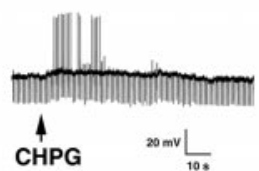

C
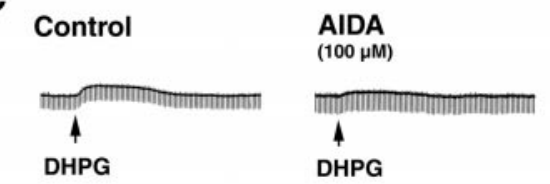

Wash

D

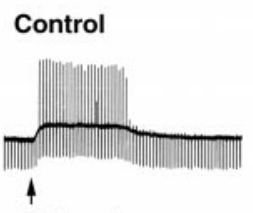

MPEP

$(100 \mu \mathrm{M})$
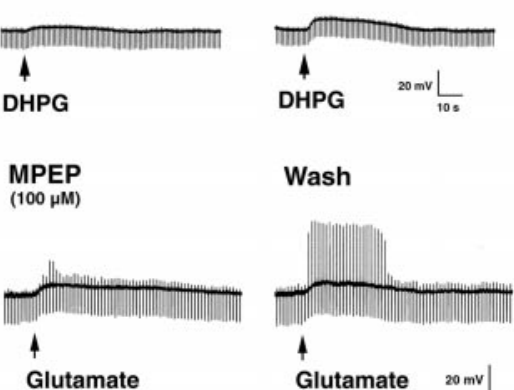

Glutamate

Glutamate

\section{E}

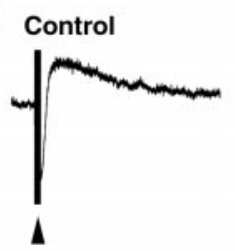

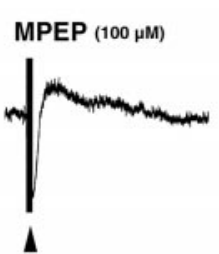

ChAT-immunoreactive (Fig. 2G) submucosal neurons exhibited pCREB immunoreactivity after distension. In the presence of AIDA, pCREB immunoreactivity was found in the nuclei of $8.2 \pm 1.8 \%$ of ChAT-positive cells ( $n=100$ ChAT-positive cells) (Fig. $2 I$ ). In the myenteric plexus, $100 \pm 2.3 \%$ of calbindinimmunoreactive neurons exhibited pCREB immunoreactivity after distension (Fig. $2 H$ ). No pCREB-calbindin-immunoreactive neurons were found in gut treated with AIDA $(n=200$ calbindin-positive cells) (Fig. $2 J$ ); however, pCREB immunoreactivity was found in a small subset of neurons that did not contain calbindin.

\section{Glutamate and group I mGluR-specific agonists evoke a depolarizing response in submucosal neurons}

Intracellular records were obtained from submucosal neurons ( $n=65$; resting membrane potential, $-51.50 \pm 0.79 \mathrm{mV}$; input resistance, $124.35 \pm 4.80 \mathrm{M} \Omega$ ) to determine whether, as the immunocytochemical data outlined above suggests, these cells express functional group I mGluRs. Recordings were obtained from S-type cells because they contain VIP (Jiang et al., 1993) and appear to express mGluR5 (see above). In current clamp, using TTX (300 nM) to eliminate possible presynaptic effects of the drug, microejection of glutamate evoked a slow depolarization $(6.57 \pm 0.64 \mathrm{mV})$, associated with spike activity, in most of the neurons examined (22 of 25, 88\%) (Fig. 3A,D). Effects of glutamate on input resistance were variable $(-23.0-21.9 \%$ of control). Depolarizing responses were evoked by the mGluR5-selective agonist CHPG $(4.5 \pm 0.8 ; n=5$ ) (Fig. $3 B$ ), and input resistance increased $(16.3 \pm 2.5$ of control). In addition, depolarizing responses were evoked by DHPG $(5.8 \pm 0.9 \mathrm{mV} ; n=10)$ (Fig. $3 C$ ) and quisqualate $(6.9 \pm 0.6 ; n=5)$. Input resistance increased to $14.1 \pm 3.4$ and $2.5 \pm 0.9 \%$ of control, respectively. Superfusion of the group I antagonist $S$-4CPG dose-dependently reduced the depolarizing response to glutamate to $74.10 \pm 3.39 \%(10 \mu \mathrm{M} ; n=$ $4), 59.23 \pm 4.51 \%(100 \mu \mathrm{M} ; n=4)$, and $43.09 \pm 5.61 \%(500 \mu \mathrm{M}$; $n=4)$ of the control $(p<0.05)$ (Fig. $3 A)$. $S$-4CPG also reduced the membrane depolarization evoked by CHPG $(n=3)$ (Fig. $3 B)$. Depolarizing responses to DHPG were suppressed by the group I antagonist AIDA $(n=4)$ (Fig. $3 C$ ). In contrast, depolarizing responses to group I agonists were not affected by superfusion of the group II antagonist MCCG $(100 \mu \mathrm{M} ; n=3)$. These findings support the idea that glutamate exerts its excitatory effects in the submucosal plexus by recruiting group I mGluRs to directly modulate postsynaptic membrane properties.

To determine whether depolarizing responses to glutamate involved mGluR5 receptors, we examined the effects of the selective mGluR5 antagonist MPEP (Gasparini et al., 1999; Salt et al., 1999). MPEP dose-dependently reduced the slow depolarizing response to superfusion of glutamate $(10 \mu \mathrm{M})$ to $84.16 \pm$ $3.26 \%(1 \mu \mathrm{M} ; n=3), 65.60 \pm 7.64 \%(10 \mu \mathrm{M} ; n=3)$, and $62.55 \pm$ $4.36 \%(100 \mu \mathrm{M} ; n=3)$ of the control $(p<0.05)$ (Fig. $3 D)$. MPEP also reduced the depolarizing response evoked by superfusion of CHPG $(1 \mathrm{~mm})$ to $59.33 \pm 1.26 \%$ of the control $(n=3 ; p<0.05)$. Moreover, MPEP concentration-dependently decreased the amplitude of slow EPSPs to $74.37 \pm 3.90 \%(1 \mu \mathrm{M} ; n=9), 63.77 \pm$ $5.21 \%(10 \mu \mathrm{M} ; n=9)$, and $54.39 \pm 6.12 \%(100 \mu \mathrm{M} ; n=12)$ of the control $(p<0.05)$ (Fig. $3 E)$. Thus, mGluR5 contributes, at least in part, to slow responses evoked by glutamate and slow synaptic excitation of submucosal neurons. 


\section{DISCUSSION}

The present experiments show that functional group I mGluRs are present in the ENS and demonstrate that they undergo agonist- and reflex-evoked internalization. Neurons in both the myenteric and submucosal plexus displayed clusters of mGluR5 immunoreactivity that were localized on the plasma membrane. Exposure to the group I mGluR agonist DHPG induced a loss of membrane fluorescence in cultured neurons, which was blocked by coapplication of the group I mGluR antagonist AIDA. This finding indicates that agonist binding induces internalization of mGluR5, similar to other G-protein-coupled receptors.

Studies on whole mounts of ileum demonstrate that agitation of the villi by bubbling is sufficient to induce mGluR5 internalization in submucosal neurons. The internalization is almost certainly caused by the release of glutamate from neurons, because endogenous glutamate is only present in neurons in the guinea pig ileum (Liu et al., 1997). Thus, reflexes that are evoked by villous agitation, which must use intrinsic primary afferent neurons, interneurons, and motoneurons (Gershon et al., 1994), can be deduced to involve glutamatergic neurons that act on neurons that express mGluR5. Submucosal intrinsic primary afferent neurons appear to be a likely source for glutamate released onto mGluR5 in the ENS. These neurons are glutamatergic, and glutamatergic nerve fibers innervate both submucosal and myenteric ganglia (Liu et al., 1997). The finding that AIDA blocked the reflex-evoked internalization of mGluR5 and reduced the expression of pCREB in enteric neurons evoked by distension of the gut lumen provides further support for the idea that group I mGluRs participate in enteric reflexes. Moreover, the finding that the selective mGluR5 antagonist MPEP reduced stimulus-evoked slow EPSPs in submucosal neurons supports the idea that mucosal stimulation is activating mechanosensitive pathways that use mGluR5 to excite neurons in submucosal ganglia.

mGluR5-positive neurons in the submucosal plexus were predominantly noncholinergic and contained VIP, a marker of secretomotor cells (Keast, 1987). Their function is to stimulate the secretion of water and electrolytes into the intestinal lumen (Cooke, 1998). Both asparagine and glutamate are stimulants of $\mathrm{Cl}^{-}$secretion (Rhoads et al., 1995). VIP-containing submucosal neurons are S-type cells (Jiang et al., 1993). Consistent with the demonstration that these cells display mGluR5 immunoreactivity, glutamate and group I mGluR-specific agonists evoked a slow depolarizing response in S-type neurons. The response was blocked by the group I mGluR antagonists $S$-4CPG, AIDA, and MPEP. In addition, MPEP suppressed stimulus-evoked slow EPSPs in S-type cells. Thus, secretomotor neurons express functional group I mGluRs that mediate a slow depolarizing response to glutamate, and slow synaptic excitation of these cells involves mGluR5. Activation of mGluR1 may also be involved, because guinea pig submucosal neurons express the $\mathrm{mGluR} 1 \alpha$ subtype (Kirchgessner and Liu, 1996).

A subset of mGluR5-positive neurons in the myenteric plexus contained calbindin. Calbindin is found in $\sim 80 \%$ of neurons that exhibit a pronounced afterhyperpolarization (AH), which is caused by the activation of a $\mathrm{Ca}^{2+}$-activated $\mathrm{K}^{+}$conductance. Neurons with AH-type behavior are considered intrinsic primary afferent neurons in the guinea pig ileum (Furness et al., 1998). Glutamate evokes both fast and slow depolarizing responses in AH-type neurons (Liu et al., 1997). The fast response appears to be mediated by AMPA receptors because it is blocked by AMPA receptor antagonists and potentiated by cyclothiazide. The slow response has been attributed to NMDA receptors, because it is mimicked by NMDA and reduced by NMDA antagonists. The presence of mGluR5 immunoreactivity on a subset of calbindinpositive cells suggests that slow responses to glutamate could also be attributable to activation of group I mGluRs.

mGluR5 immunoreactivity was also found on myenteric neurons that did not contain calbindin. These cells consist of interneurons and motoneurons that innervate smooth muscle (Furness et al., 1994; Costa et al., 1996), and activation of mGluRs on these cells would be expected to modulate motility. The presence of mGluRs on different subsets of enteric neurons suggests that mGluR-mediated glutamate responsivity is not limited to $\mathrm{AH}$ neurons, a suggestion that was confirmed by the observation that $\mathrm{S}$ neurons also exhibited slow responses to glutamate.

In summary, this study demonstrates for the first time that mGluRs undergo agonist- and reflex-evoked internalization. Internalization might be a major mechanism for regulation of mGluR activity. What causes the internalization of mGluR in enteric neurons is not known; however, a clathrin-dependent, mGluR-mediated internalization pathway has been demonstrated in olfactory receptor neurons (Rankin et al., 1999). Future experiments will determine whether similar mechanisms underlie the internalization of mGluR5.

\section{REFERENCES}

Abe T, Sugihara H, Nawa H, Shigemoto R, Mizuno N, Nakanishi S (1992) Molecular characteristics of a novel metabotropic glutamate receptor mGluR5 coupled to inositol phosphate/ $\mathrm{Ca}^{2+}$ signal transduction. J Biol Chem 267:13361-13368.

Aramori I, Nakanishi S (1992) Signal transduction and pharmacological characteristics of a metabotropic glutamate receptor, mGluR1, in transfected CHO cells. Neuron 8:757-765.

Bertrand PP, Galligan JJ (1995) Signal-transduction pathways causing slow synaptic excitation in guinea pig myenteric AH neurons. Am J Physiol 269:G710-G720.

Bornstein JC, Furness JB (1988) Correlated electrophysiological and histochemical studies of submucous neurons and their contribution to understanding enteric neural circuits. J Auton Nerv Syst 25:1-13.

Brakeman PR, Lanahan AA, O'Brien R, Roche K, Barnes CA, Huganir RL, Worley PF (1997) Homer: a protein that selectively binds metabotropic glutamate receptors. Nature 386:284-288.

Burns GA, Stephens KE (1995) Expression of mRNA for the $N$-methylD-aspartate (NMDAR1) receptor and vasoactive intestinal polypeptide (VIP) co-exist in enteric neurons of the rat. J Auton Nerv Syst 55:207210.

Burns GA, Stephens KE, Benson LA (1994) Expression of mRNA for the $N$-methyl-D-aspartate (NMDAR1) receptor by the enteric neurons of the rat. Neurosci Lett 170:87-90.

Cooke HJ (1998) "Enteric tears": chloride secretion and its neural regulation. News Physiol Sci 13:269-274.

Costa M, Brookes SJH, Steele PA, Gibbins I, Burcher E, Kandiah CJ (1996) Neurochemical classification of myenteric neurons in the guinea-pig ileum. Neuroscience 75:949-967.

Furness JB, Bornstein JC, Pompolo S, Young HM, Kunze WAA, Kelly H (1994) The circuitry of the enteric nervous system. Neurogastroenterol Mot 6:241-253.

Furness JB, Kunze WAA, Bertrand PP, Clerc N, Bornstein JC (1998) Intrinsic primary afferent neurons of the intestine. Prog Neurobiol 54:1-18.

Gasparini F, Lingenhöhl K, Stoehr N, Flor PJ, Heinrich M, Vranesic I, Biollaz M, Allgeier H, Heckendorn R, Urwyler S, Varney MA, Johnson EC, Velicelebi G, Kuhn R (1999) 2-Methyl-6-(phenylethynyl)pyridine (MPEP), a potent, selective and systemically active mGlu5 receptor antagonist. Neuropharmacology 38:1493-1503.

Gershon MD, Kirchgessner AL, Wade PR (1994) Functional anatomy of the enteric nervous system. In: Physiology of the gastrointestinal tract, Ed 3 (Johnson LR, ed), pp 381-422. New York: Raven.

Grady EF, Bohm SK, Bunnett NW (1997) Turning off the signal: mechanisms that attenuate signaling by $\mathrm{G}$ protein-coupled receptors. Am J Physiol 273:G598-G601. 
Grider JR (1994) CGRP as a transmitter in the sensory pathway mediating peristaltic reflex. Am J Physiol 266:G1139-G1145.

Jiang M-M, Kirchgessner A, Gershon MD, Surprenant A (1993) Cholera toxin sensitive neurons in guinea-pig submucosal plexus. Am J Physiol 27:G86-G94.

Keast JR (1987) Mucosal innervation and control of water and ion transport in the intestine. Rev Physiol Biochem Pharmacol 109:1-59.

Kirchgessner AL, Gershon MD (1988) Projections of submucosal neurons to the myenteric plexus of the guinea pig intestine: in vitro tracing of microcircuits by retrograde and anterograde transport. J Comp Neurol 277:487-498.

Kirchgessner AL, Liu M-T (1996) Metabotropic glutamate receptors in the enteric nervous system and pancreas. Soc Neurosci Abstr 22:1049.

Kirchgessner AL, Liu M-T (1998) Immunohistochemical localization of nicotinic acetylcholine receptors in the guinea pig bowel and pancreas. J Comp Neurol 390:497-514.

Kirchgessner AL, Liu M-T (1999) Differential localization of $\mathrm{Ca}^{2+}$ channel $\alpha 1$ subunits in the enteric nervous system: presence of $\alpha 1 \mathrm{~B}$ channel-like immunoreactivity in intrinsic primary afferent neurons. J Comp Neurol 409:85-104.

Kirchgessner AL, Tamir H, Gershon MD (1992) Identification and stimulation by serotonin of intrinsic sensory neurons of the submucosal plexus of the guinea pig gut: activity-induced expression of Fos immunoreactivity. J Neurosci 12:235-249.

Kirchgessner AL, Liu M-T, Gershon MD (1996) In situ identification and visualization of neurons that mediate enteric and enteropancreatic reflexes. J Comp Neurol 371:270-286.

Kirchgessner AL, Liu M-T, Alcantara F (1997) Excitotoxicity in the enteric nervous system. J Neurosci 17:8804-8816.

Liu M-T, Rothstein JD, Gershon MD, Kirchgessner AL (1997) Glutamatergic enteric neurons. J Neurosci 17:4764-4784.

Liu M-T, Roche KW, Wenthold RJ, Kirchgessner A (1998) Reflexevoked internalization of metabotropic glutamate receptors and ex- pression of pCREB immunoreactivity in enteric neurons. Soc Neurosci Abstr 24:1273.

Masu M, Tanabe Y, Tsuchida K, Shigemoto R, Nakanishi S (1991) Sequence and expression of a metabotropic glutamate receptor. Nature 349:760-765.

Pin JP, Duvoisin R (1995) The metabotropic glutamate receptors: structure and functions. Neuropharmacology 34:1-26.

Rankin ML, Alvania RS, Gleason EL, Bruch RC (1999) Internalization of $\mathrm{G}$ protein-coupled receptors in single olfactory receptor neurons. J Neurochem 72:541-548.

Rhoads JM, Argenzio RA, Chen W, Gomez GG (1995) Asparagine stimulates piglet intestinal $\mathrm{Cl}-$ secretion by a mechanism requiring a submucosal glutamate receptor and nitric oxide. J Pharmacol Exp Ther 274:404-412.

Roche KW, Tu JC, Petralia RS, Xiao B, Wenthold RJ, Worley PF (1999) Homer $1 \mathrm{~b}$ regulates the trafficking of group I metabotropic glutamate receptors. J Biol Chem 274:25953-25957.

Salt TE, Binns KE, Turner JP, Gasparini F, Kuhn R (1999) Antagonism of the mGlu5 agonist 2-chloro-5-hydroxyphenylglycine by the novel selective mGlu5 antagonist 6-methyl-2-(phenylethynyl)-pyridine (MPEP) in the thalamus. Br J Pharmacol 127:1057-1059.

Southwell BR, Woodman HL, Royal SJ, Furness JB (1998) Movement of villi induces endocytosis of NK1 receptors in myenteric neurons from guinea pig ileum. Cell Tissue Res 292:37-45.

Wiley JW, Lu Y, Owyang C (1991) Evidence for a glutamatergic neural pathway in the myenteric plexus. Am J Physiol 261:G693-G700.

Wong HC, Sternini C, Lloyd K, DeGiorgio R, Walsh JH (1996) Monoclonal antibody to VIP: production, characterization, immunoneutralizing activity, and usefulness in cytochemical staining. Hybridoma 15:133-139.

Yau WM, Dorsett JA, Parr EL (1989) Characterization of acetylcholine release from enzyme-dissociated myenteric ganglia. Am J Physiol 256: G233-G239. 